\title{
Pengujian Sifat Fisika dan Listrik Minyak Kelapa Sebagai Alternatif Isolasi Pada Trafo Daya
}

\section{Testing of Physical and Electrical Properties of Coconut Oil As Alternative Insulation In Power Transformers}

\author{
Ni Made Seniari ${ }^{1}{ }^{*}$, Sumawarti $^{1}$, IK Wiryajati ${ }^{1}$, Supriyatna $^{1}$, \\ I.A.Sri Adnyani ${ }^{1}$, Bagus Widhi Dharma. ${ }^{2}$ \\ ${ }^{1}$ Jurusan Teknik Elektro, Fakultas Teknik, Universitas Mataram \\ ${ }^{2}$ Jurusan Teknik Sipil Universitas Qamarul Huda Badaruddin Bagu (UNIQHBA) Lombok Tengah
}

*Corresponding Author Email: seniari_nimade@unram.ac.id

Manuscript received: 08-12-2020. Accepted: 28-10-2021

\begin{abstract}
ABSTRAK
Bahan isolasi minyak trafo merupakan hasil proses dari minyak bumi, bahan yang tak dapat diperbaharui, semakin langka, mahal, komoditi import, serta kebutuhan semakin meningkat. Sehingga perlu di upayakan minyak trafo alternatif yang berasal dari bahan renewable, berbasis produksi dalam negeri, meningkatkan nilai tambah suatu comoditi serta ramah lingkungan. Minyak trafo alternatif dalam hal ini adalah minyak kelapa. Untuk itu perlu uji spesifikasi kelayakan minyak kelapa sebagai alternative minyak trafo meliputi pengujian sifat fisika, kimia dan listrik. Hasil uji di bandingkan dengan standart minyak trafo mengacu pada IEC. Hasil pengujian, titik nyala dan kekuatan dielektrik layak, massa jenis, koofesien muai volume dan kekentalan minyak kelapa belum layak digunakan sebagai alternatif minyak isolasi trafo daya. Persentase ditinjau dari sifat fisika sebesar 25\%, dengan 4 pengujian dari 10 sifat fisika yang ada. Kelayakan sifat listrik sebesar $50 \%$ dengan 1 pengujian dari 2 sifat listrik yang ada
\end{abstract}

Kata kunci:minyak; trafo; listrik; fisika; kimia

\begin{abstract}
Transformer oil insulation material is the result of processes from petroleum, the material that is not able to be renewed, increasingly scarce, expensive, an imported commodity, and the need is increasing. So it is necessary to strive for alternative transformer oil that comes from renewable materials, based on domestic production, increases the added value of a commodity and environmentally friendly. The alternative transformer oil in this case is coconut oil. For this reason, it is necessary to test the feasibility of coconut oil as an alternative to transformer oil which includes testing of physical, chemical and electrical properties. The test results are compared with the standard transformer oil according to the IEC. The test results, the flashpoint and dielectric strength are feasible as an alternative to transformer oil, the density, volume expansion coefficient and viscosity of coconut oil are not suitable for use as an alternative to power transformer insulation oil. The percentage in terms of physical properties is $25 \%$, with 4 tests of 10 existing physical properties. The feasibility of electrical properties is $50 \%$ with 1 test of 2 existing electrical properties.
\end{abstract}

Keyword: transformer oil; coconut; electrical; physical 


\section{PENDAHULUAN}

Minyak trafo terbuat dari pengolahan minyak bumi yang tidak dapat di perbaharui. Merk minyak trafo yang beredar di pasaran adalah merk Iso, Nynas, Shell diala B, Petronas dll. Harganya relatif mahal, keberadaannya semakin langka, merupakan komoditi import dari berbagai negara. Untuk itu perlu di upayakan alternative minyak trafo yang lain, yang lebih murah, dapat diperbaharui dan bisa diproduksi dalam negeri. Untuk itu di lakukan uji spesifikasi minyak yang dapat diperbaharui antara lain minyak jarak, minyak biji ketapang dan minyak kelapa sebagai alternatif pengganti minyak trafo. (Rendy P. K.; Murdiya F M., 2017), (Juniarti, 2006).

Dalam penelitian ini upayakan minyak kelapa sebagai alaternatif minyak trafo karena Indonesia adalah salah satu produsen minyak kelapa sawit terbesar didunia (http://www.suarapembaruan.com). Harga minyak goreng tahun 2020 rata-rata 11.000/liter, sedangkan harga minyak trafo jenis Shell Diala B dan Iso tahun 2020 rata-rata 38.500/liter. Disamping lebih harganya lebih murah, minyak kelapa bersifat renewable sehingga bisa menjamin kesinambungan produksi. Minyak kelapa dan minyak kelapa sawit juga merupakan industri berbasis produksi dalam negeri, ramah lingkungan dan dapat meningkatkan nilai tambah buah kelapa.

Sebelum minyak kelapa di upayakan sebagai minyak trafo alternatif dan dapat digunakan sebagai pengganti minyak trafo, terlebih dahulu harus memenuhi spesifikasi teknis minyak trafo baik sebagai media isolasi dan sebagai media pendingin. Untuk itu perlu di lakukan uji standarisasi minyak trafo dari sifat fisika, kimia dan elektrik. Sebagai media isolasi minyak trafo harus memiliki kekuatan dielektrik atau tegangan tembus yang tinggi. Kekuatan dielektrik yaitu, kesanggupan bahan isolasi untuk menahan terjadinya tegangan tembus atau Breakdown Voltage yang dinyatakan dalam $\mathrm{kV} / 2,5 \mathrm{~mm}$ (sifat listrik minyak trafo). Sebagai media pendingin, minyak trafo harus dapat menghantarkan panas ke udara luar agar tidak terjadi pemanasan yang berlebih dalam trafo tersebut (sifat fisika minyak trafo).

Untuk itu perlu di uji bagaimana pengaruh pemanasan terhadap massa jenis, koofesien muai volume, kekentalan dan flash point (tititk nyala), kekuatan dielektrik minyak kelapa. Dari pengujian tersebut di dapat keputusan layak dan tidak layak minyak kelapa sebagai minyak trafo sesuai standar IEC (IEC Publication 156, 1995).

Penelitian minyak kelapa telah dilakukan oleh beberapa orang antara lain. Hasyim Asy'ari, Jatmiko (2004), meneliti tentang perubahan suhu terhadap tegangan tembus pada bahan isolasi cair menggunakan minyak trafo shell Diala $B$ dan minyak pelumas jenis Mesran Super SAE 40, di panaskan pada suhu ruangan $\left(27{ }^{\circ} \mathrm{C}\right)$ sampai suhu $100{ }^{\circ} \mathrm{C}$ dengan selang suhu $10{ }^{\circ} \mathrm{C}$. Semakin meningkat suhu maka tegangan tembusnya semakin meningkat.

Penelitian tegangan tembus minyak kelapa murni sebagai isolasi cair dengan variasi elektroda uji. Pengujian menggunakan sepasang elektroda setengah bola, elektroda dan elektroda bidang-setengah bola, dengan jarak antara elektroda di variasikan. Hasil tegangan tembus minyak kelapa 29,17 kV/2,5 mm, lebih kecil dari standar IEC. Jadi minyak kelapa belum layak sebagai minyak trafo di lihat dari kemampuan tegangan tembusnya (Budiyantoro dkk, 2011). 


\section{BAHAN DAN METODE}

Alat

Peralatan utama yang dipakai pada penelitian ini dibagi menjadi 4 yaitu peralatan pengujian massa jenis, viskositas, flash point dan pengujian tegangan tembus.

Peralatan Pengujian Massa Jenis meliputi timbangan Analitik dengan ketelitian 0.1 gram, gelas ukur dengan kapasitas $25 \mathrm{ml}$, termometer, kompor listrik dan panci aluminium. Peralatan pengujian viskositas (kekentalan) terdiri dari penyumbat lubang tabung viscosimeter, termometer untuk viskositas Saybolt, termometer untuk bak peredam, saringan dengan ukuran saringan no. 100, labu penampung $60 \mathrm{ml}$, stopwatch, Saybolt viscometer ASTM D-36-70, gelas ukur kecil, piknometer, tang penjepit. Peralatan pengujian Flash Point (titik nyala) terdiri dari termometer, Cleveland open cup (cawan kuningan), pelat pemanas, yang bagian atas dilapisi seluruhnya oleh asbes setebal $0.6 \mathrm{~cm}(1 / 4)$ dan nyala penguji. Peralatan pengujian tegangan tembus VDE 0370 meliputi : kompor listrik, termometer, desikator, gelas ukur dengan kapasitas $250 \mathrm{ml}$, tisu dan panci aluminium.

\section{Sampel Pengujian}

Sampel pengujian adalah :

- Minyak kelapa sawit kemasan merk $A, B, C, D, E$ yang di jual di pasar tradisional atau supermarket,

- Minyak kelapa murni yang di buat secara manual, selanjutnya di sebut "minyak kelapa".

- Minyak trafo sampel sebagai pembanding

\section{Metode Perhitungan}

Menghitung massa jenis dan koofesien muai volume minyak kelapa pada suhu ruangan $\left(27^{\circ} \mathrm{C}\right)$ yaitu :

$$
\begin{aligned}
& \rho_{t}=\frac{m_{r}}{V_{o}}, \\
& \text { Volume tetap }\left(V_{o}\right)=25 \mathrm{ml} \\
& \begin{aligned}
\rho_{t} & =\frac{22,50 \mathrm{~g}}{25 \mathrm{ml}} \\
& =0,9 \mathrm{~g} / \mathrm{ml} \text { atau } \\
\rho_{t} & =0,9 \mathrm{~kg} / \mathrm{dm}^{3} \text { dimana } 1 \text { Liter }=1 \mathrm{dm}^{3} \\
\rho_{t} & =\frac{m_{o}}{V_{t}},
\end{aligned}
\end{aligned}
$$




$$
\begin{aligned}
& \rho_{t}=\frac{m_{o}}{V_{t}}, \\
& \text { massa awal tetap }\left(m_{\circ}\right)=22,50 \mathrm{ml} \\
& 0,9 \mathrm{~g} / \mathrm{ml}=\frac{22,50}{V_{t}} \\
& V_{t} \times 0,9 \mathrm{~g} / \mathrm{ml}=22,50 \mathrm{~g} \\
& V_{t} \quad=\frac{22,50 \mathrm{~g}}{0,9 \mathrm{~g} / \mathrm{ml}} \\
& V_{t} \quad=25 \mathrm{ml} \\
& \Delta V \quad=V_{t}-V_{0} \\
& \Delta V \quad=25 \mathrm{ml}-25 \mathrm{ml} \\
& \Delta V \quad=0 m l
\end{aligned}
$$

\section{Langkah-langkah Pengujianan}

\section{Pengujian Massa Jenis.}

Pengujian massa jenis minyak diawali dengan menimbang gelas ukur kosong dan menimbang gelas ukur yang diisi minyak dengan volume awal tetap sebanyak $25 \mathrm{ml}$. Selanjutnya dihitung selisih berat antara minyak dan gelas ukur dengan gelas ukur kosong. Kemudian minyak dipanaskan dengan menggunakan kompor listik dari suhu $27{ }^{\circ} \mathrm{C}$ sampai dengan $120{ }^{\circ} \mathrm{C}$. Dilakukan penimbangan kembali setiap selang suhu $20{ }^{\circ} \mathrm{C}$. Pengujian sebanyak 3 kali untuk masing-masing merek minyak.

\section{Pengujian Viskositas (Kekentalan)}

Menuangkan air kedalam viskometer sampai level yang yang telah ditentukan dalam spesifikasi alat, memasukkan minyak pada tempatnya sampai level yang telah ditentukan, kemudian menghidupkan stop kontak (tombol on) viskometer untuk memanaskan air. Selanjutnya menyiapkan gelas penampung, tepat dibawah tempat pengeluaran minya stop kontak di matikan. Minyak dan air uji tersebut diukur temperarturnya dengan termometer. Setelah temperatur $38{ }^{\circ} \mathrm{C}$, kemudian sumbatan pada gelas ukur dilepaskan dan membiarkan minyak menetes kedalam labu pengukur $60 \mathrm{ml}$. Waktu yang diperlukan minyak menetes untuk mencapai garis batas $60 \mathrm{ml}$ dicatat dengan nenggunakan stopwatch.

Dengan cara yang sama dapat dilakukan untuk masing-masing kombinasi suhu dari suhu ruangan sampai suhu $100{ }^{\circ} \mathrm{C}$ dan dilakukan pengujian setiap selang $20{ }^{\circ} \mathrm{C}$. Pengulangan pengujian yang sama sebanyak 3 kali untuk masing-masing merek minyak.

\section{Langkah Pengujian Flash Point (Titik Nyala)}

Mengisi cawan Cleveland dengan minyak uji sampai garis pada cawan kemudian di panaskan, dengan api pemanas berada pada jarak $7,5 \mathrm{~cm}$ dari titik tengah cawan. Meletakkan thermometer tegak lurus didalam benda uji dengan jarak 6,4 $\mathrm{mm}$ di atas dasar cawan, dan terletak pada satu garis yang menghubungkan titik tengah cawan dan titik poros nyala penguji. Kemudian posisi poros thermometer diatur pada jarak $1 / 4$ diameter cawan dari tepi. Selanjutnya dipanaskan $(15 \pm 1){ }^{\circ} \mathrm{C}$ per menit sampai benda uji mencapai suhu $56^{\circ} \mathrm{C}$ dibawah titik nyala perkiraan. 
Kecepatan pemanasan selanjutnya diatur $5-6{ }^{\circ} \mathrm{C}$ per menit pada suhu antara $56-28{ }^{\circ} \mathrm{C}$ di bawah titik nyala perkiraan. Nyala pengujian diatur pada diameter nyala penguji tersebut menjadi 3,2 sampai 4,8 mm. Nyala pengujian diputar-putar sehingga melalui permukaan cawan (dari tepi ke tepi cawan), dalam waktu 1 detik. Mengulang pekerjaan tersebut setiap kenaikan $2^{\circ} \mathrm{C}$. Pengujian dilakukan sampai terlihat nyala singkat pada suatu titik diatas permukaan benda uji, kemudian mencatat temperaturnya. Pengujian tersebut dilakukan sebanyak tiga kali untuk satu merek minyak, dihitung nilai temperatur rata-ratanya.

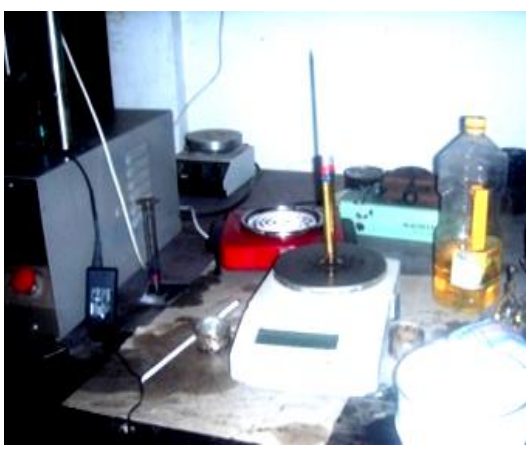

Gambar 1. Alat Timbangan Analitik Dan Gelas Ukur

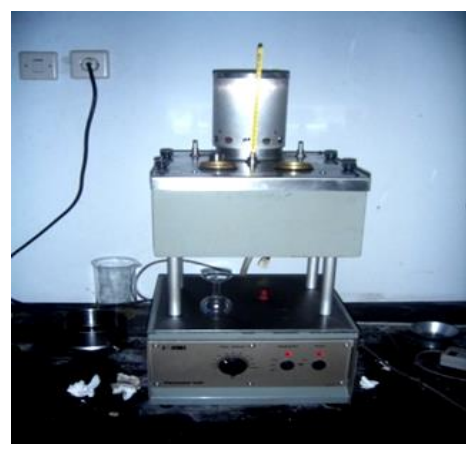

Gambar 2. Skematik SayboltViscosimeterASTM 36-70

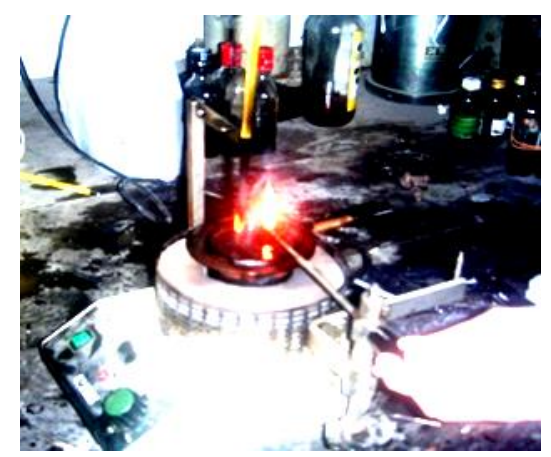

Gambar 3. Cleavend Open Cup

\section{Pengujian Tegangan Tembus}

Pengujian tegangan tembus diawali dengan pembersihan peralatan - peralatan uji. Elektroda dalam tabung pengujian juga harus dicuci dengan minyak yang akan diuji. Selanjutnya minyak sampel di uapkan dengn melakukan pemanasan pada titik didih air (100 ${ }^{o} \mathrm{C}$ ). Untuk menjaga agar minyak tetap bebas dari air digunakan Desikator yang dilengkapi dengan silika gel untuk menyerap kelembaban. Pengujian tegangan tembus minyak atau pengujian kekuatan dielektri minyak dilakukan sebelum dan setelah penguapan. Pengujian menggunakan gelombang sinus tegangan tinggi AC dengan frekuensi $50 \mathrm{~Hz}$, sehingga diperlukan pembangkitan tegangan tinggi $\mathrm{AC}$, menggunakan transformator dengan perbandingan belitan yang tinggi. Gelas uji minyak standar menggunakan Tipe VDE 0370, sebagai wadah untuk menguji kekuatan dielektrik minyak sebelum maupun setelah diuapakan, dengan jarak sela elektroda yaitu 2,5 $\mathrm{mm}$.

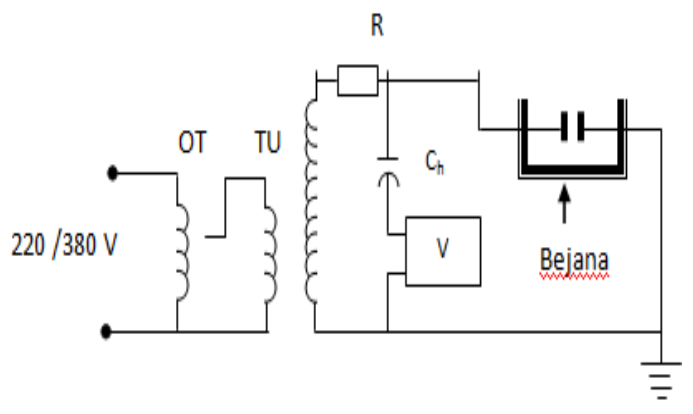

a. Skematis Alat Test Tegangan Tembus Minyak Trafo (Tobing L Bonggas, 2002)

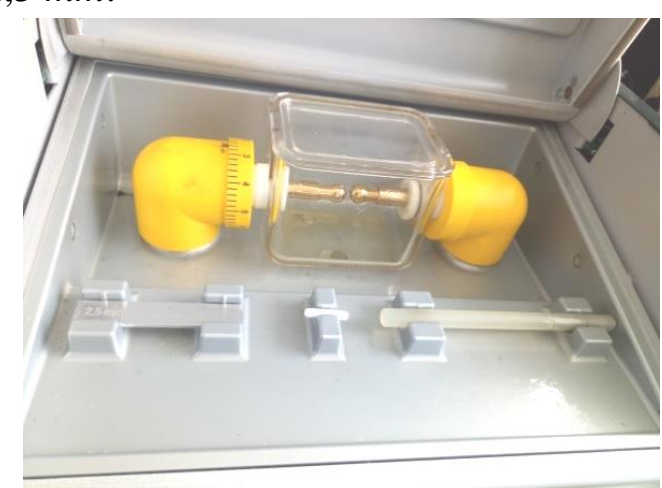

b. Alat Test Tegangan Tembus Minyak Trafo (Kamilatin J, 2021)

Gambar 4. A Skematis dan alat test tegangan tembus tinyak trafo 
Pengujian tegangan tembus minyak dilakukan dengan menempatkan minyak uji pada bejana sampai seluruh elektroda yang berjarak $2,5 \mathrm{~mm}$ terendam dengan minyak uji. Alat tegangan tembus minyak mendapat suplay dari PLN 220/380 Volt, dan oleh trafo step-up tegangan alat uji tersebut dinaikkan menjadi kilo-Volt. Setelah alat uji "ON " dan tegangan alat uji secara otomatis naik bertahap yaitu sebesar 2-3 $k V$ per detik. Apabila tegangan tersebut tidak mampu ditahan oleh minyak uji, maka akan timbul loncatan api dari elektroda pada minyak dan alat pengaman bekerja memutus daya. Pencatatan dilakukan saat berapa Kilo-Volt alat pengaman Circuit Breaker akan bekerja memutus daya, terlihat pada layar monitor. Pengambilan data sebanyak 5 kali berturut-turut. Kemudian minyak dipanaskan dari suhu $27{ }^{\circ} \mathrm{C}$ sampai dengan $120^{\circ} \mathrm{C}$ dan diuji kembali kekuatan dielektriknya setiap selang $20^{\circ} \mathrm{C}$. Minyak yang telah diuapkan dengan pemanasan juga diuji dengan cara yang sama

\section{HASIL DAN PEMBAHASAN}

Pengujian kelayakan minyak kelapa dan minyak kelapa sawit sebagai alternatif minyak trafo daya, serta pengujian minyak trafo yang sedang digunakan, mengacu pada statandar-standar pada tabel 1.

Tabel 1. Standar pengujian Sifat Fisika Minyak Trafo

\begin{tabular}{|c|c|c|c|}
\hline \multirow[t]{2}{*}{ No } & \multirow{2}{*}{ Spesifikasi } & \multicolumn{2}{|c|}{ Standar Minyak Trafo } \\
\hline & & Acuan & Besaran \\
\hline \multicolumn{4}{|c|}{ Pengujian sifat Fisika } \\
\hline 1 & Massa jenis $\left(\mathrm{kg} / \mathrm{dm}^{3}\right)$ & IEC 296 & $0,895\left(20^{\circ} \mathrm{C}\right)$ \\
\hline \multirow[t]{2}{*}{2} & \multirow{2}{*}{$\begin{array}{l}\text { Koofesien muai volume pada suhu } 25^{\circ} \mathrm{C} \\
\text { sampai } 100{ }^{\circ} \mathrm{C}\end{array}$} & ASTM & 0,0007 \\
\hline & & D1903 & $\begin{array}{l}\text { sampai } \\
0,0008\end{array}$ \\
\hline 3 & Kekentalan (cSt) pada suhu $40^{\circ} \mathrm{C}$ & IEC 296 & 11 \\
\hline 4 & Titik nyala $\left({ }^{\circ} \mathrm{C}\right)$ & IEC 296 & 130 \\
\hline 5 & Daya melarutkan zat lain & 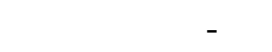 & - \\
\hline 6 & Daya hantar panas & - & - \\
\hline 7 & Titik beku & - & - \\
\hline 8 & Warna & - & - \\
\hline 9 & Spesifik gravitasi & - & - \\
\hline 10 & Tegangan Permukaan & - & - \\
\hline & Pengujian Sifat Listrik & & \\
\hline & a.Tegangan tembus & IFC 296 & $30-60 \mathrm{kV}$ \\
\hline 1 & sebelum penguapan & & \\
\hline & $\begin{array}{l}\text { b.Tegangan tembus } \\
\text { setelah penguapan }\end{array}$ & IEC 296 & $30-60 \mathrm{kV}$ \\
\hline 2 & Faktor Kebocoran Dielektrik & - & - \\
\hline
\end{tabular}

\section{Hasil Pengujian Massa Jenis Dan Koofisien Muai Volume}

Specific Gravity (SG) adalah perbandingan antara massa jenis dari minyak dengan massa jenis air pada suhu $4{ }^{\circ} \mathrm{C}$. Hubungan antara Specific Gravity dan massa jenis dapat dilihat pada persamaan berikut. 


$$
\text { Specific Gravity }(S G)=\frac{\rho_{b b}}{\rho_{\text {air }} \operatorname{suhu} 4^{\circ} \mathrm{C}}
$$

Dengan :

$$
\begin{aligned}
& \rho_{b b}: \text { Massa jenis zat cair }\left(\mathrm{kg} / \mathrm{m}^{3}\right) \\
& \rho_{\text {air }}: \text { Massa jenis air padasuhu } 4^{\circ} \mathrm{C}
\end{aligned}
$$

Hasil pengujian dan perhitungan massa jenis dan koofesien muai volume minyak kelapa

\begin{tabular}{|c|c|c|c|c|c|c|c|c|}
\hline $\begin{array}{c}T \\
{ }^{0} \mathrm{C} \\
\end{array}$ & $\begin{array}{c}\Delta t \\
{ }^{0} \mathrm{C} * *\end{array}$ & $\begin{array}{l}V_{o} \\
m l\end{array}$ & $\begin{array}{c}m_{r} \\
(\operatorname{gram}) * *\end{array}$ & $\begin{array}{l}\rho_{t} * * \\
g / m l\end{array}$ & $\begin{array}{c}m_{o} \\
\text { gram }\end{array}$ & $\begin{array}{c}V t * * \\
m l \\
\end{array}$ & $\begin{array}{c}\Delta V^{* *} \\
m \boldsymbol{l}\end{array}$ & $\begin{array}{c}\gamma * * \\
/{ }^{0} \mathrm{C} \\
\end{array}$ \\
\hline 27 & 0 & 25 & 22.50 & 0.9000 & 22.50 & 25.000 & 0.000 & 0.0000 \\
\hline 40 & 20 & 25 & 21.73 & 0.8692 & 22.50 & 25.886 & 0.886 & 0.0018 \\
\hline 60 & 20 & 25 & 21.67 & 0.8668 & 22.50 & 25.958 & 0.958 & 0.0019 \\
\hline 80 & 20 & 25 & 21.30 & 0.8520 & 22.50 & 26.408 & 1.408 & 0.0028 \\
\hline 100 & 20 & 25 & 21.20 & 0.8480 & 22.50 & 26.533 & 1.533 & 0.0031 \\
\hline 120 & 20 & 25 & 21.10 & 0.8440 & 22.50 & 26.659 & 1.659 & 0.0033 \\
\hline
\end{tabular}
ditampilkan pada tabel 2.

Tabel 2. Hasil pengujian Massa Jenis dan koofesien muai volume minyak kelapa.

Keterangan tabel :

$T=$ Temperatur pengujian $\left({ }^{\circ} \mathrm{C}\right)$

$m \quad=$ Massa zat cair $(\mathrm{kg})$ atau $(\mathrm{g})$

$m_{r} \quad=M \rho_{t}=$ Massa jenis $\left(\mathrm{kg} / \mathrm{dm}^{3}\right)(\mathrm{g} / \mathrm{ml})$

$m_{o} \quad=$ Massa awal zat cair $(\mathrm{kg})$

$V_{t}=$ Volume akhir zat cair $(\mathrm{kg})$ atau $(\mathrm{g})$

$\Delta t=$ Perubahansuhu $\left({ }^{\circ} \mathrm{C}\right)$

$\gamma \quad=$ Koofesien muaivolume $\left({ }^{\circ} C^{-1}\right)$

$\Delta V=$ Perubahanvolume benda $\left(\mathrm{m}^{3}\right)$

* = Hasil Pengujian massa rata-rata zat cair $(\mathrm{kg})$ atau $(\mathrm{g})$

$\mathrm{V}_{\mathrm{o}} \quad=$ Volume awal (mula-mula) $(\mathrm{kg})$ atau $(\mathrm{g})$

$* *$ = Hasil Perhitungan

Gambar.5 menunjukkan bahwa untuk masing-masing minyak, semakin tinggi suhu minyak massa jenis cenderung turun. Pada suhu ruangan $\left(27^{\circ} \mathrm{C}\right)$ massa jenis rata-rata minyak kelapa sawit paling besar yaitu sebesar $0,9097 \mathrm{~kg} / \mathrm{dm}^{3}$ turun menjadi $0,8386 \mathrm{~kg} / \mathrm{dm}^{3}$ pada suhu $120{ }^{\circ} \mathrm{C}$. Massa jenis minyak dipengaruhi oleh temperatur pengujian, semakin besar temperatur pengujian maka semakin kecil massa jenis minyak yang dihasilkan. Disisi lain massa jenis zat cair juga dipengaruhi oleh massa molekul penyusun zat cair tersebut, dimana semakin besar massa molekul penyusunannya maka semakin besar pula massa jenisnya.

\section{Hasil Pengujian Koofisien Muai Volume}

Gambar 6 menunjukkan untuk masing-masing minyak bahwa semakin tinggi suhu minyak maka nilai rata-rata koofesien muai volume cenderung naik. Berbeda dengan massa jenis, semakin besar temperatur pengujian maka semakin besar koofesien minyak yang dihasilkan. Ini disebabkan karena pada pengujian koofesien muai volume semakin tinggi suhu minyak maka minyak tersebut akan memuai seiring dengan kenaikan suhu. 


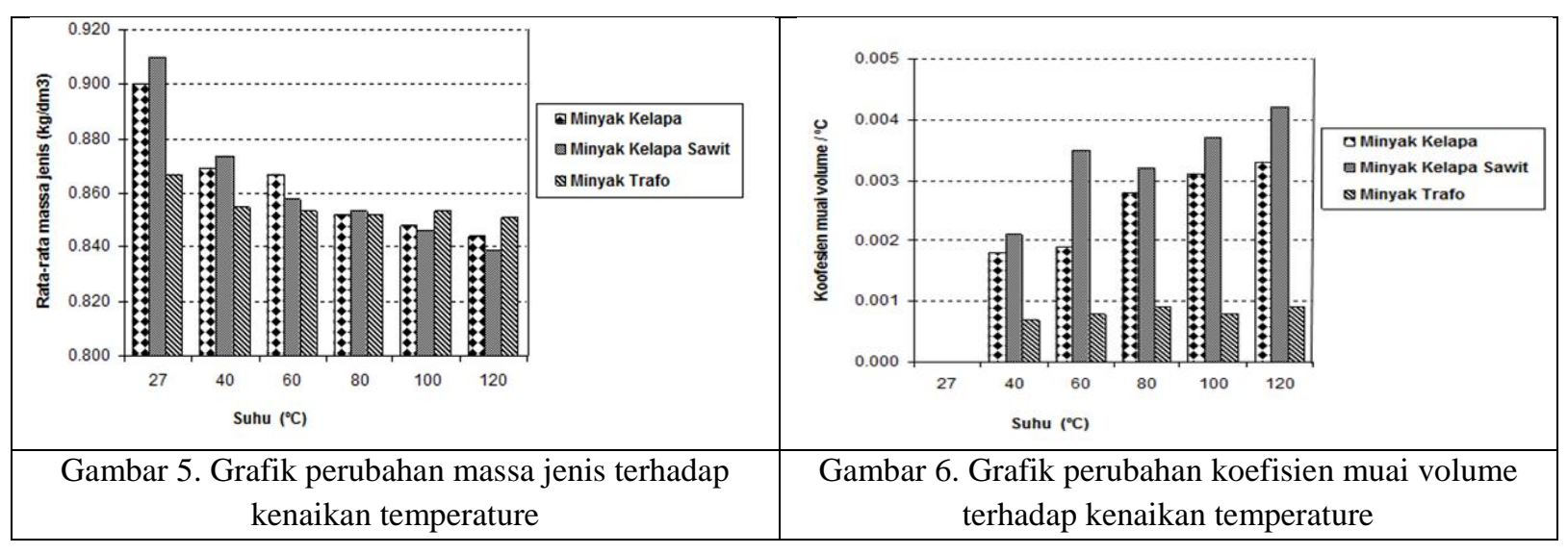

\section{Hasil Pengujian Viskositas Kinematik (Kekentalan)}

Harga kinematic viscosity dalam Stoke diperoleh dari persamaan dalam tabel 3. Dengan $t$ adalah waktu yang diperlukan untuk memenuhi tabung $60 \mathrm{~cm}^{3}$ dalam satuan detik.

Tabel 3. Harga Kinematic Viscosity $m$

\begin{tabular}{rc}
\hline Saybolt Universal & Kinematic Viscosity \\
\hline $31<\mathrm{t}<100$ & $\mathrm{~V}=0,00226 . \mathrm{t}-1,95 / \mathrm{t}$ \\
$\mathrm{t} \geq 100$ & $\mathrm{~V}=0,00220 . \mathrm{t}-1,35 / \mathrm{t}$ \\
\hline
\end{tabular}

(Sumber : Tjokrowisastro dkk, 1990)

Hasil pengujian viskositas kinematik minyak kelapa yang di buat secara manual di tunjukkan tabel 4.

Tabel 4. Viskositas kinematik minyak kelapa murni pada temperatur meningkat.

\begin{tabular}{cccccc}
\hline $\boldsymbol{T}$ & & $\boldsymbol{S U S}(\boldsymbol{t})$ & $($ detik) $*$ & SUS $\left(\boldsymbol{t}_{\boldsymbol{r}}\right)$ & Viskositas Kinematik (v) \\
$(\boldsymbol{c S t}) * *$ \\
\hline${ }^{\boldsymbol{C}}$ & $\mathbf{1}$ & $\mathbf{2}$ & $\mathbf{3}$ & $($ detik $) * *$ & 38,20 \\
\hline 27 & 177,41 & 177,12 & 177,15 & 177,14 & 37,73 \\
40 & 173,10 & 173,9 & 172,95 & 173,31 & 26,96 \\
60 & 123,07 & 122,94 & 123,05 & 123,02 & 10,37 \\
80 & 60,03 & 60,15 & 60,53 & 60,24 & 9,81 \\
100 & 58,21 & 58,33 & 58,15 & 58,23 & \\
\hline
\end{tabular}

Keterangan :

$T=$ Temperatur minyak $\left({ }^{\circ} \mathrm{C}\right)$

SUS $(\mathrm{t})=$ Waktu yang diperlukan minyak untuk memenuhi tabung $60 \mathrm{ml}$ (Saybolt Universal Second) (detik).

$S U S\left(\mathrm{t}_{\mathrm{r}}\right)=$ Waktu rata-rata yang diperlukan minyak untuk memenuhi tabung $60 \mathrm{ml}$.

Untuk mendapatkan Viskositas kinematik minyak digunakan perhitungan sebagai berikut dengan contoh perhitungan minyak kelapa pada temperatur $\left(27^{\circ} \mathrm{C}\right)$.

$$
\begin{aligned}
v & =0,00220 \cdot t_{r}-\frac{1,35}{t_{r}} \\
& =0,00220 \cdot 177,14-\frac{1,35}{177,14} \\
& =0,3820 \mathrm{St} \\
& =38,20 \mathrm{cSt}
\end{aligned}
$$


Dengan cara yang sama seperti diatas, maka dapat diperoleh Viskositas kinematik dari minyak trafo dan keempat merek minyak kelapa sawit dengan hasil ditunjukkan pada gambar 7.

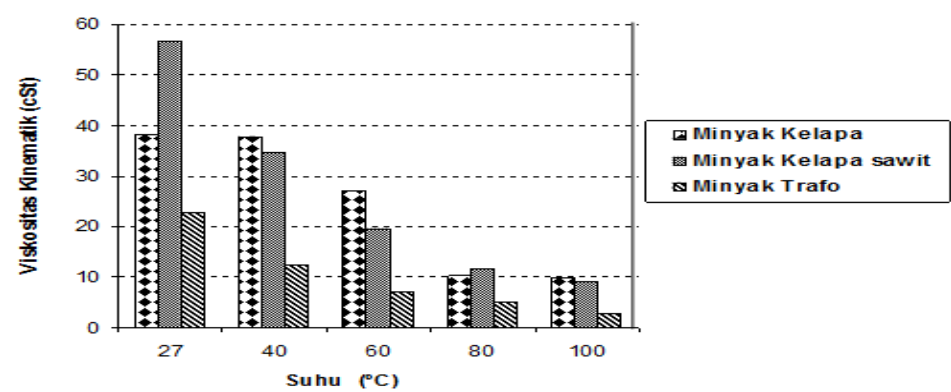

Gambar 7. Grafik perubahan viskositas kinematik minyak terhadap kenaikan temperature

Grafik 7 menunjukkan bahwa semakin tinggi suhu minyak, viskositas minyak cenderung turun. Pada suhu ruangan kekentalan paling besar terjadi pada minyak kelapa sawit sebesar 56,67 cSt. Viskositas menunjukkan ketahanan (resistansi) zat cair terhadap aliran, sehingga semakin besar waktu yang diperlukan minyak mengalir dari viscosimeter untuk memenuhi tabung penampung, maka semakin besar pula viskositas minyak tersebut. Minyak yang memiliki viskositas yang lebih tinggi lebih sulit untuk dialirkan daripada minyak yang memiliki viskositas yang lebih rendah. Besarnya viskositas dipengaruhi oleh massa jenis. Suatu fluida yang mempunyai massa jenis yang besar maka fluida tersebut akan semakin sulit untuk mengalir.

\section{Hasil Pengujian Flash Point}

Hasil pengujian Flash Point (titik nyala) minyak ditunjukkan tabel 5.

Tabel 5. Hasil pengujian flash point minyak

\begin{tabular}{cc}
\hline Jenis minyak & Flash pointSuhu $\left({ }^{0} C\right)$ \\
\hline Minyak kelapa Murni (Curah) & 291 \\
percobaan 1 & 290 \\
percobaan 2 & 291 \\
percobaan 3 & 290,67 \\
rata-rata & \\
Minyak kelapa Sawit & 309,75 \\
percobaan 1 & 309,75 \\
percobaan 2 & 310 \\
percobaan 3 & 309,83 \\
rata-rata & \\
percobaan 1 & 149 \\
percobaan 2 & 148 \\
percobaan 3 & 149 \\
rata-rata & 148,67 \\
\hline
\end{tabular}

Flash point (titik nyala) adalah temperatur pada keadaan dimana uap diatas minyak akan terbakar dengan cepat (meledak) apabila nyala api didekatkan padanya. Pengujian Flash point minyak dilakukan dengan menggunakan alat Cleveland Open Cup. 
Flash point (titik nyala) dipengaruhi oleh proses penguapan dimana semakin cepat minyak tersebut menguap flash pointnya akan semakin rendah. Proses penguapan adalah proses perubahan zat cair menjadi gas, pada dasarnya semua gas mengalami penguapan pada temperatur yang berbeda-beda. Proses penguapan zat cair itu dipengaruhi oleh massa jenis, dimana semakin tinggi massa jenisnya maka semakin sulit zat cair itu menguap.

\section{Hasil Pengujian Tegangan Tembus}

Pengujian tegangan tembus minyak dilakukan sebelum penguapan dan sesudah penguapan dengan melakukan pemanasan ditunjukkan tabel 6, gambar 8 dan 9. Dalam pengujian minyak diatas suhu $100^{\circ}$ dilakukan dengan tujuan bahwa pengujian pada temperature $100^{\circ}$ kandungan air dalam minyak sudah habis menguap.

Tabel 6. Nilai rata-rata hasil pengujian tegangan tembus minyak sebelum dan setelah peguapan dengan pemanasan.

\begin{tabular}{ccccccc}
\hline & \multicolumn{2}{c}{ Rata-rata tegangan tembus sebelum } & \multicolumn{3}{c}{ Rata-rata tegangan tembus setelah } \\
pemurnian dengan pemanasan $(\mathrm{kV})$
\end{tabular}

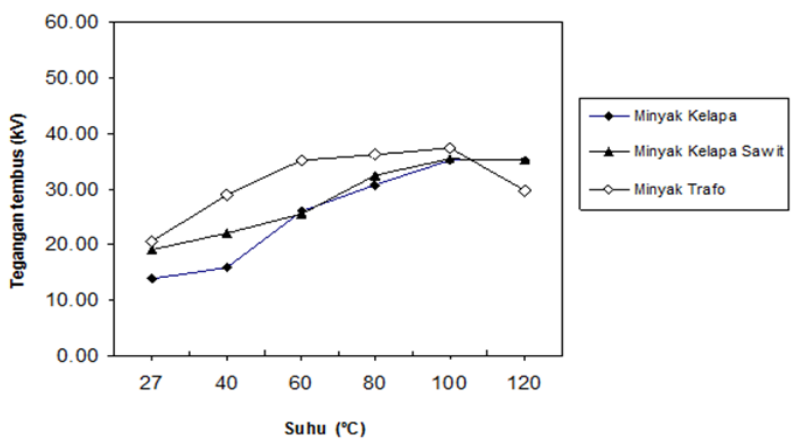

Gambar 8. Grafik tegangan tembus minyak terhadap kenaikan temperatur sebelum penguapan

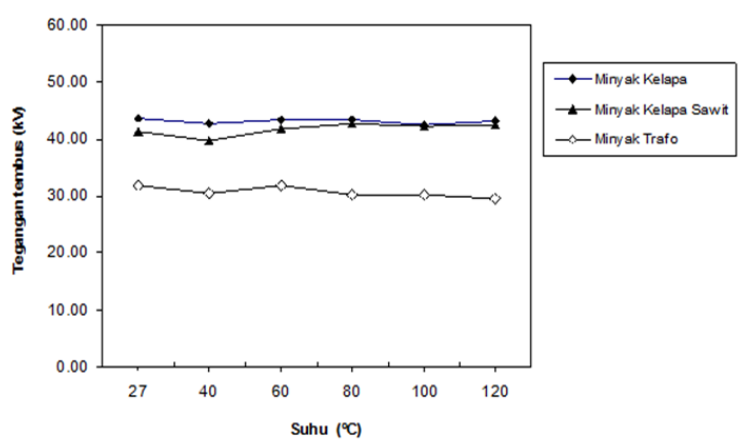

Gambar 9. Grafik tegangan tembus minyak terhadap kenaikan temperatur setelah penguapan

Gambar 8 menunjukkan hasil pengujian tegangan tembus minyak yang cenderung naik untuk minyak yang belum dimurnikan dengan pemanasan. Kenaikan tegangan tembus minyak berhenti pada suhu $100{ }^{\circ} \mathrm{C}$. Semakin tinggi suhu, kadar air dalam minyak semakin berkurang karena telah terjadi penguapan, sehingga tegangan tembus minyak semakin tinggi. Pada suhu diatas $100{ }^{\circ} \mathrm{C}$ kadar air dalam minyak sudah sangat sedikit sehingga meskipun suhu minyak dinaikkan, tegangan tembus minyak cenderung tetap.

Tabel 6 dan gambar 9, menunjukkan bahwa tegangan tembus minyak relatif tetap untuk minyak yang telah dimurnikan dengan pemanasan. Pada minyak yang telah dimurnikan 
dengan pemanasan kadar air dalam minyak sangat sedikit, sehingga meskipun suhu minyak dinaikkan, tegangan tembus minyak relatif tetap. Hasil pengujian menunjukkan bahwa tegangan tembus minyak kelapa dan minyak kelapa sawit juga memenuhi standar sebagai sebagai alternatif minyak trafo daya

Tabel 7. Resume hasil pengujian dan kelayakan minyak sebagai alternatif minyak trafo daya, beserta standar-standar acuan.

\begin{tabular}{|c|c|c|c|c|c|c|c|c|c|c|}
\hline \multirow[t]{2}{*}{ No } & \multirow{2}{*}{ Spesifikasi } & \multicolumn{2}{|c|}{$\begin{array}{c}\text { Standar Minyak } \\
\text { Trafo }\end{array}$} & \multirow{2}{*}{$\begin{array}{c}\text { Hasil } \\
\text { Pengujian } \\
\text { Minyak } \\
\text { Trafo } \\
\end{array}$} & \multicolumn{3}{|c|}{$\begin{array}{c}\text { Hasil Pengujian Minyak } \\
\text { Kelapa }\end{array}$} & \multicolumn{3}{|c|}{$\begin{array}{c}\text { Hasil Pengujian } \\
\text { Minyak Kelapa Sawit }\end{array}$} \\
\hline & & Acuan & Besaran & & $\overline{\text { Besaran }}$ & Layak & $\begin{array}{l}\text { Tidak } \\
\text { Layak }\end{array}$ & Besaran & Layak & $\begin{array}{l}\text { Tidak } \\
\text { Layak }\end{array}$ \\
\hline & $\begin{array}{l}\text { Pengujian sifat } \\
\text { Fisika }\end{array}$ & & & & & & & & & \\
\hline 1 & $\begin{array}{l}\text { Massa jenis } \\
\left(\mathrm{kg} / \mathrm{dm}^{3}\right)\end{array}$ & $\begin{array}{l}\text { IEC } \\
296\end{array}$ & $\begin{array}{l}0,895 \\
\left(20^{\circ} \mathrm{C}\right)\end{array}$ & $\begin{array}{l}0,8668 \\
\left(27^{\circ} \mathrm{C}\right)\end{array}$ & $\begin{array}{c}0,9000 \\
\left(27^{\circ} \mathrm{C}\right)\end{array}$ & & $\sqrt{ }$ & $\begin{array}{l}0,9097 \\
\left(27^{\circ} \mathrm{C}\right)\end{array}$ & & $\sqrt{ }$ \\
\hline 2 & $\begin{array}{l}\text { Koofesien muai } \\
\text { volume pada suhu } \\
25^{-} 100^{\circ} \mathrm{C}\end{array}$ & $\begin{array}{l}\text { ASTM } \\
\text { D1903 }\end{array}$ & $\begin{array}{l}0,0007 \\
\text { sampai } \\
0,0008\end{array}$ & 0,00064 & 0,00192 & & $\sqrt{ }$ & 0,0025 & & $\sqrt{ }$ \\
\hline 3 & $\begin{array}{l}\text { Kekentalan }(\mathrm{cSt}) \\
\text { pada suhu } 40^{\circ} \mathrm{C}\end{array}$ & $\begin{array}{l}\text { IEC } \\
296\end{array}$ & 11 & 12,33 & 37,73 & & $\sqrt{ }$ & 34,56 & & $\sqrt{ }$ \\
\hline 4 & Titik nyala $\left({ }^{\circ} \mathrm{C}\right)$ & $\begin{array}{l}\text { IEC } \\
296\end{array}$ & 130 & 148,57 & 290,67 & $\sqrt{ }$ & & 309,83 & $\sqrt{ }$ & \\
\hline 5 & $\begin{array}{l}\text { Daya melarutkan } \\
\text { zat lain }\end{array}$ & - & - & - & - & - & - & - & - & - \\
\hline 6 & Daya hantar panas & - & - & - & - & - & - & - & - & - \\
\hline 7 & Titik beku & - & - & - & - & - & - & - & - & - \\
\hline 8 & Warna & - & - & - & - & - & - & - & - & - \\
\hline 9 & Spesifik gravitasi & - & - & - & - & - & - & - & - & - \\
\hline 10 & $\begin{array}{l}\text { Tegangan } \\
\text { Permukaan } \\
\text { Pengujian Sifat } \\
\text { Listrik }\end{array}$ & - & - & - & - & - & - & - & - & - \\
\hline & a.Tegangan tembus & IEC & $30-60$ & $\begin{array}{r}20,52 \\
\left(27^{\circ} \mathrm{C}\right)\end{array}$ & $\begin{array}{r}14,00 \\
\left(27^{\circ} \mathrm{C}\right)\end{array}$ & & $\sqrt{ }$ & $\begin{array}{r}19,15 \\
\left(27^{\circ} \mathrm{C}\right)\end{array}$ & & $\sqrt{ }$ \\
\hline 1 & $\begin{array}{l}\text { sebelum } \\
\text { penguapan }(k V)\end{array}$ & 296 & $\mathrm{kV}$ & $\begin{array}{c}38,32 \\
\left(100^{\circ} \mathrm{C}\right)\end{array}$ & $\begin{array}{r}35,32 \\
\left(100^{\circ} \mathrm{C}\right)\end{array}$ & $\sqrt{ }$ & & $\begin{array}{l}35,44 \\
\left(100^{\circ}\right)\end{array}$ & $\sqrt{ }$ & \\
\hline & b.Tegangan & IEC & $30-60$ & $\begin{array}{l}31,74 \\
\left(27^{\circ} \mathrm{C}\right)\end{array}$ & $\begin{array}{r}43,52 \\
\left(27^{\circ} \mathrm{C}\right)\end{array}$ & $\sqrt{ }$ & & $\begin{array}{l}41,27 \\
\left(27^{\circ} \mathrm{C}\right)\end{array}$ & $\sqrt{ }$ & \\
\hline & $\begin{array}{ll}\text { tembus } & \text { setelah } \\
\text { penguapan } & (\mathrm{kV})\end{array}$ & 296 & $\mathrm{kV}$ & $\begin{array}{l}30,14 \\
\left(100^{\circ}\right)\end{array}$ & $\begin{array}{r}42,56 \\
\left(100^{\circ}\right)\end{array}$ & $\sqrt{ }$ & & $\begin{array}{l}42,34 \\
\left(100^{\circ} \mathrm{C}\right)\end{array}$ & $\sqrt{ }$ & \\
\hline 2 & $\begin{array}{l}\text { Faktor Kebocoran } \\
\text { Dielektrik }\end{array}$ & - & - & - & - & & - & - & - & \\
\hline
\end{tabular}

\section{KESIMPULAN}

Hasil uji seluruh minyak kelapa dibandingkan dengan standart minyak trafo mengacu pada IEC dan ASTM. Titik nyala dan kekuatan dielektrik minyak kelapa dan minyak kelapa sawit layak sebagai minyak trafo. Massa jenis, koofesien muai volume dan kekentalan minyak kelapa belum layak digunakan sebagai alternatif minyak isolasi trafo daya. Persentase kelayakan minyak kelapa dan minyak kelapa sawit sebagai minyak trafo di tinjau dari sifat fisika sebesar 25\%, dengan 4 pengujian dari 10 sifat fisika yang ada. Kelayakan sifat listrik sebesar 50\% dengan 1 pengujian dari 2 sifat listrik yang ada. Jadi minyak kelapa perlu mendapat perlakuan khusus sebelum digunakan sebagai minyak trafo daya. 


\section{Ucapan Terima Kasih}

Terimakasih disampaikan kepada Ketua dan staf laboratorium Transportasi Teknik Sipil Universitas Mataram, Ketua dan staf laboratorium Kimia Analitik Universitas Mataram dan PT. PLN Cabang Mataram. Terimakasih juga untuk Universitas Mataram dari Tingkat Rektorat sampai lembaga-lembaga jajaran di bawahnya (LPPM), hingga penelitian, seminar Nasional dan paper ini bisa di laksanakan dan di terbitkan. Terimakasih kepada semua temanteman yang ikut terlibat dalam penelitian ini.

\section{DAFTAR PUSTAKA}

Asy'ari Hasyim, Jatmiko, 2004, Pengaruh Perubahan Suhu Terhadap Tegangan Tembus Pada Bahan Isolasi Cair, Teknik Elektro Universitas Muhammadiyah Surakarta. http://eprints.ums.ac.id/12/1/Emitor_HSY_Pengaruh Perubahan_Suhu Teg Tembus

Budiyantoro E., 2011, Analisis Tegangan Tembus Minyak Kelapa Murni Sebagai Osolasi Cair Dengan Variasi Elektroda Uji, Tugas Akhir Jurusan Teknik Elektro, Universitas Diponogoro Semarang

IEC Publication 156, 1995, Insulating Liquids-Determination of The Breakdown Voltage at Power Frequency-Test Method,

Juniarti, 2006, Pengaruh Variasi Pelarut Terhadap Mutu Minyak Biji Ketapang (Terminalia Catappa L.), Skripsi Jurusan Kimia FMIPA, Universitas Sriwijaya, Inderalaya.

Kamilatin J, 2021, Uji Kelayakan Minyak Biji Ketapang Sebagai Bahan Isolasi Cair Transformator, Sekripsi mahasiswa Jurusan Teknik Elktro,Universitas Mataram.

Pratiwi AM., Nurkamiden K., Putra FE., 2020, Pengaruh Penambahan Fenol Terhadap Tegangan Tembus Minyak Transformator, Jurnal Teknologi Terpadu, Volume 2, ISSN 2338-66649

Rendy P.K., Fri M, 2017, Karakteristik tegangan tembus arus bolak-balik pada minyak jarak pagar (Jatropa Curcas) Sebagai Alternatif Minyak Isolasi Cair, Jurnal Jom FTEKNIK, Vol.4, No. 2, 2017.

Tobing Bonggas L., 2002, Dasar Teknik Pengujian Tegangan Tinggi, PT Gramedia Pustaka Utama, Jakarta. 